NUREG/CR-0628

1979

PNL-2889 REV.

RE

1-

\title{
Prediction of the Net Radon Emission From a Model Open Pit Uranium Mine
}

\author{
K. K. Nielson \\ R. W. Perkins \\ L. C. Schwendiman \\ w. I. Enderlin
}

September 1979

Prepared for

the U.S. Nuclear Regulatory Commission under a Related Services Agreement with the U.S. Department of Energy

Contract EY-76-C-06-1830

Pacific Northwest Laboratory Operated for the U.S. Department of Energy by Battelle Memorial Institute

\section{Ballielle}




\title{
NOTICE
}

This report was prepared as an account of work sponsored by the United States Government. Neither the United States nor the United States Nuclear Regulatory Commission, nor any of their employees, nor any of their contractors, subcontractors, or their employees, makes any warranty, express or implied, or assumes any legal liability or responsibility for the accuracy, completeness or usefuiness of any information, apparatus, product or process disclosed, or represents that its use would not infringe privately owned rights.

\author{
PACIFIC NORTHWEST LABORATORY \\ operated by \\ BATTELLE \\ for the \\ UNITED STATES DEPARTMENT OF ENERGY \\ Under Contract EY-76-C-06-1830
}
Printed in the United States of America Available from
National Technical Information Service
United States Department of Cornmerce
5285 Port Royal Road
Springfield, Virginia 22151

Price: Printed Copy $\$$

*; Microfiche $\$ 3.00$

NTIS

•Pages Selling Price

001-025 $\quad 4.00$

026-050 \$4.50

051-075 $\$ 5.25$

076-100 $\quad \$ 6.00$

$101-125 \quad 36.50$

$126-150 \quad \$ 7.25$

$151.175 \quad \$ 8.00$

$176-200 \quad \$ 9.00$

201-225 $\$ 9.25$

226-250 $\quad \$ 9.50$

251-275 $\$ 10.75$

$276-300 \quad \$ 11.00$ 
NUREG/CR-0628

PNL-2889 REV

RE

$\underline{\text { NOTE }}$

This is a revision of an earlier document of the same name and number dated March, 1979. This current revision supersedes and replaces the March document, all copies of which should be destroyed. 
NUREG-CR-0628

PNL-2889 (Rev.)

RE

PREDICTION OF THE NET RADON EMISSION FROM A MODEL OPEN PIT URANIUM MINE
K. K. Nielson
R. W. Perkins
L. C. Schwendiman
W. I. Enderlin

September 1979

Prepared for

the U. S. Nuclear Regulatory Commission under a Related Services Agreement with the U. S. Department of Energy under Contract EY-76-C-06-1830

Fin No. B-2279

Pacific Northwest Laboratory

Richland, Washington 99352 
TABLE OF CONTENTS

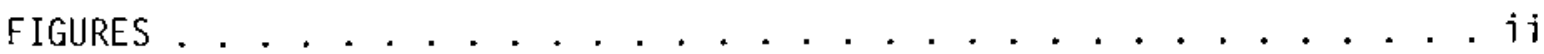

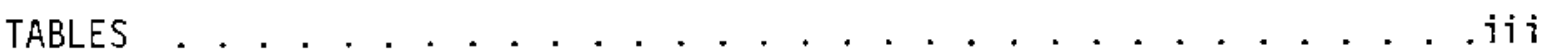

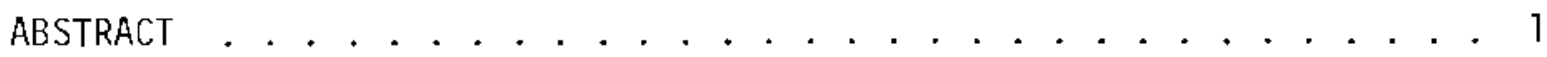

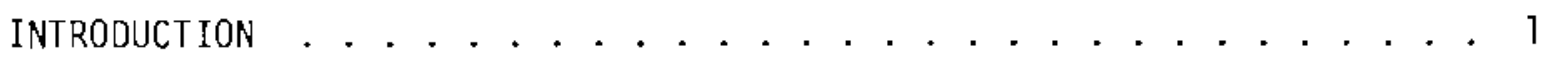

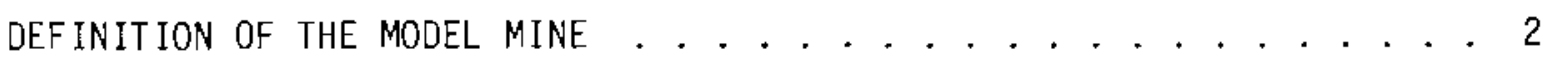

PRELIMINARY CALCULATIONS . . . . . . . . . . . . . . 12

Effective Surface Area of Ore Stockpiles . . . . . . . . 12

Surface Area of the Subore Pile . . . . . . . . . 12

Dimensions and Surface Areas of the Pits ......... . 13

Surface Area of Ore and Subore in the Pits........ . 13

Surface Area of Overburden in Active and Developing

Pits, Refilled Pits, Dump Piles, and the Abandoned Pit. . . . . 14

Area of Original Land Surface Affected by the Mine . . . . . . . 14

Radon Exhalation Rate ............. 15

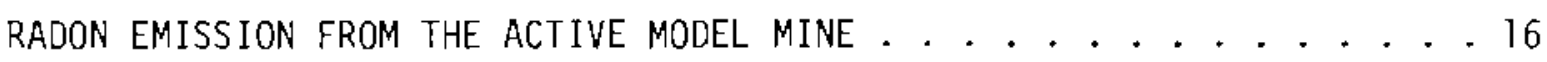

RADDN EMISSION FROM THE INACTIVE OR ABANDONED MINE. . . . . . 18

COMPARISON OF RADON EMISSION WITH BACKGROUND LEVELS . . . . . . 19

SUMMARY . . . . . . . . . . . . . . . . . . . . 20

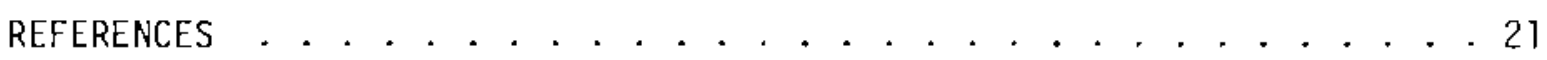




\section{FIGURES}

?. Schematic 0pen Pit... . . . . . . . . . . . . . . . . 6

2. Model Open Pit Uranium Mining Operation. . . . . . . . . . . . 7

3. Schematic Illustration of the Model Mine Near the Middle..... . 8 of Its Active Lifetime, and in Its Inactive or Abandoned Status 


\section{TABLES}

I. Open Pit Uranium Mines Used for Averaging for . . . . . . . . . 3 the Model Mine

II. Modei Mine Parameters Averaged from Eight Open . . . . . . . . 4 Pit Uranium Mines

III. Estimates of the Radon Flux Exhaled from the . . . . . . . . 16 Ground Surface

IV. Net Radon Emissions from the Active Mine . . . . . . . . . . 17

V. Net Radon Emissions from the Inactive or ...........19 Abandoned Mine 

PREDICTION OF THE NET RADON EMISSION FROM A MODEL OPEN PIT URANIUM MINE

\section{ABSTRACT}

Radon emission from a model open pit uranium mining operation has been estimated by applying radon exhalation fluxes measured in an open pit uranium mine to the various areas of the model mine. The model mine was defined by averaging uranium concentrations, mine dimensions, production and procedura) statistics for eight major open pit uranium mines in the Casper, Wyoming area. The resulting emission rates were $630 \mathrm{Ci} / \mathrm{RRY}$ * during mining operations and $26 \mathrm{Ci} / \mathrm{RRY} / \mathrm{yr}$ after abandonment of the mine assuming $100 \%$ recovery of $\mathrm{U}_{3} \mathrm{O}_{8}$ from the ore, or $700 \mathrm{Cj} / \mathrm{RRY}$ and $29 \mathrm{Ci} / \mathrm{RRY} / \mathrm{yr}$ assuming $90.5 \%$ recovery.

\section{INTRODUCTION}

In connection with the decision of the Nuclear Regulatory Commission (NRC) to re-examine the basis of the radon entry in the 5-3 table, Pacific Northwest Laboratory entered into a contract with the NRC in 1978 to measure radon releases from open pit uranium mines. The measurements, which require an extensive and complicated field sampling program, wili continue at least into 1980 in order to provide an assessment of radon releases during a variety of mining and seasonal conditions. In order to provide the NRC with an interim estimate of radon releases from open pit mining, this report predicts these releases from selected mine parameters and measured radon exhalation fluxes.

The present revised report supersedes the April, 1979 report by the same name and document number, and contains definitions and units consistent with other pertinent NRC documents. It also corrects some minor technical inconsistencies and attempts to provide a clear elucidation of the methods and basis for predicting the releases of radon from open pit uranium mining. The following estimates were originally made to serve as a guide to the related field sampling program and necessarily involve many

${ }^{\star} R R Y=$ Reference Reactor Year is a 1000 Mwe reactor operating for one year. In this report, the fuel requirement for the reference reactor year is taken to be 182 metric tons (tonnes) of $\mathrm{U}_{3} \mathrm{O}_{8}$. Taking into account milling recovery of $90.5 \%$, the requirement of $\mathrm{U}_{3} \mathrm{O}_{8}$ in the ore as mined is taken to be 201 metric tons. 
assumptions. Their value as an interim representation of the $U$. S. open pit uranium mining industry is based on their being the best presentlyavailable estimates of mine parameters and radon fluxes, and their being consistent with anticipated future trends in open pit uranium mining practices.

Radon-222, herein called radon, is exhaled continuously from virtually all exposed soil and rock surfaces due to the ubiquitous distribution of uranium, and hence radium, in these materials. The exhalation flux increases linearly with the parent radium concentration, assuming all other parameters remain constant. Since radjum $\left({ }^{26} R a\right)$ and its parent uranium $(238 \mathrm{U})$ generally occur in equilibrium if considered on the size scale of a large open pit mine, radon can reasonably be said to be exhaled from soil or rock surfaces in proportion to their uranium concentrations for the average case. The total radon exhalation from a given surface can thus be estimated as the product of the uranium concentration, the surface area, and a standard value of the radon flux per unit area and per unit ore grade. Radon fluxes from various types of surfaces can then be summed to estimate the total radon emission rate for an open pit mining operation. We have used this approach to predict radon emissions from a "model" or average open pit uranium mine based on eight Wyoming open pit mines. This method clearly avoids the complications of radon diffusion characteristics, and simply depends on the representativeness with which the surface areas, ore grades, and standard radon flux can be estimated. This model includes all known significant radon sources from open pit mining up to the delivery of ore to the mill, but does not include radon releases during milling or tailings disposal.

\section{DEFINITION OF THE MODEL MINE}

The model mine is defined by the average of selected parameters from ejght major open pit uranium mines in the Casper, Wyoming area. These mines were visited in June, 1978, and were observed to all be represented by having relatively dry, sandy roll-front deposits of uranium ore. The combined production of the eight Wyoming mines studied is about 4500 tonnes $U_{3} 0_{8} / y r$, or about $65 \%$ of the tota? U.S. $U_{3} O_{8}$ production from open pit mines in $1977 .{ }^{1}$ Further, the sedimentary sandstone formations which characterize the Wyoming 
mines are also similar to those of the New Mexico open pit mines, where mining methods are also similar. It is bel jeved that a model mine defined by the average of selected parameters from the eight major open pit uranium mines in the Casper, Wyoming area listed in Table $I$ is an adequate characterization of the uranium open pit mining operations in the U. S. with regard to radon emissions. An exception to the present model with respect to size is Anaconda's Jackpile-Paguate complex, which annualiy produces more than four times the uranium of the model mine, ${ }^{2}$ but affects less than twice the land surface area. ${ }^{3}$ Since its average ore grade ${ }^{2}$ is onty slightly higher than that from the model mine, radon emission per unit uranium production would be expected to be similar to that from the composite of the eight Wyoming uranium mines. It is readily apparent that an individual mine could be quite different from the composite model mine due to the range of parameters, but our supposition is believed reasonable that the composite represents a better estimate than that for any individual mine. Research underway is expected to yield more definitive radon release values. Should fieid measurements underway or justified refinements in model parameters be forthcoming, we would undertake to modify the radon release values based on the model herein described.

Through discussions with resident mine managers and engineers, characteristic data on production, ore grades, depths of ore, and other pertinent parameters were obtained. These data are sumarized in Table II by the indicated averages and ranges.

TABLE I

\section{Open Pit Uranium Mines Used for Averaging for the Model Mine}

1. Federal American Partners

2. Western Nuclear Mine

3. Big Eagle Mine

4. Exxon's Highland Operation

5. Morton Ranch Operation

6. Bear Creek Uranium Mine

7. Pathfinder Shirley Basin Mine

8. Getty Petrotomics Mine
Riverton, Wyoming Jeffrey City, Wyoming Jeffrey City, Wyoming Casper, Wyoming Casper, Wyoming Casper, Wyoming Shirley Basin, Wyoming Shirley Basin, Wyoming 
TABLE II

Model Mine Parameters Averaged from Eight Open Pit Uranium Mines

Expected mine life ${ }^{(a)}$

Ore production

Average ore grade

Average cutoff grade

Thickness of overburden

Thickness of ore zone

Ore stockpile residence time

overburden/ore ratio (b)

Number of pits $(b)$

\begin{tabular}{ll}
\multicolumn{1}{c}{ Mean } & \multicolumn{1}{c}{ Range } \\
years & $10-20$ years \\
1560 tonnes/day & $910-2700$ tonnes/day \\
$0.11 \% \mathrm{U}_{3} 0_{8}$ & $0.065-0.79 \% \mathrm{U}_{3} 0_{8}$ \\
$0.03 \% \mathrm{U}_{3} \mathrm{O}_{\mathrm{B}}$ & $0.02-0.05 \% \mathrm{U}_{3} 0_{8}$ \\
$64 \mathrm{~m}$ & $0-110 \mathrm{~m}$ \\
$12 \mathrm{~m}(\mathrm{c})$ & $0.3-61 \mathrm{~m}$ \\
$41 \mathrm{days}(\mathrm{c})$ & $4-180$ days \\
77 & $30-110$ \\
7 & $5-9$
\end{tabular}
(a) Data available from six of the mines
(b) Data avaijable from four of the mines
(c) Geometric mean calculated from a log-nomal distribution 
In accordance with the data in Table II, the model mine is considered to consist of a sequence of discrete pits in various stages of excavation, mining, and reclamation. One pit is always being actively mined. Each pit is defined as the inverted frustum of a right circular cone having $45^{\circ}$ sloping sides as illustrated in Figure 1. The cone consists of an upper zone composed entirely of overburden, and a lower zone containing ore, subore, and overburden as illustrated in Figure 2. All ore is considered to be of the average production grade in Table II $\left(0.11 \% \mathrm{U}_{3} 0_{8}\right)$, while subore is defined to be one-half the average cutoff grade in Table II, or $0.015 \% \mathrm{U}_{3} \mathrm{O}_{8}$.

The subore thus represents material containing uranium which is detectable but of insufficient grade to presently be economically useful. It is also known as protore, protore resource, mineral, low-grade or waste, and is commonly set aside from overburden for possible future use. Subore is assumed to be mined in quantities equal to the ore production, and is accumulated in a continually growing pile throughout the life of the mine. The subore pile is modeled as the frustum of a right circular cone with $45^{\circ}$ sloping sides. Its height is defined to be $30.5 \mathrm{~m}(100 \mathrm{ft})$, and its radius increases as subore is added. It should be recognized that although the accumulation of subore is a common practice, it was not encountered in all of the mines. With continually improving mill capabilities and the use of lower grade ores, the inclusion of subore in this model may tend to slightly overestimate radon releases from future mining operations. .

The geometry of the ore stockpiles is typically that of a wedge, which nominally has a ramp length of $200 \mathrm{ft}$, a ramp width of $60 \mathrm{ft}$, a maximum height of $30 \mathrm{ft}$, and $45^{\circ}$ sloping sides. Overburden piles are considered to be identical in geometry to the open pits and are merely inverted as illustrated in Figure 3. Although most of the pile edges taper to a thickness which is less than the relaxation length for radon diffusion $(\sim 1 \mathrm{~m})$, the resulting decrease in radon exhalation from these "thin" surfaces is at least qualitatively compensated by the normal spillage and mixing in the environs of all of the stockpile and dump areas.

The distribution of ore and subore in the ore zone of the pit is highly variable, with discrete ore pods ranging from less than a meter to more 


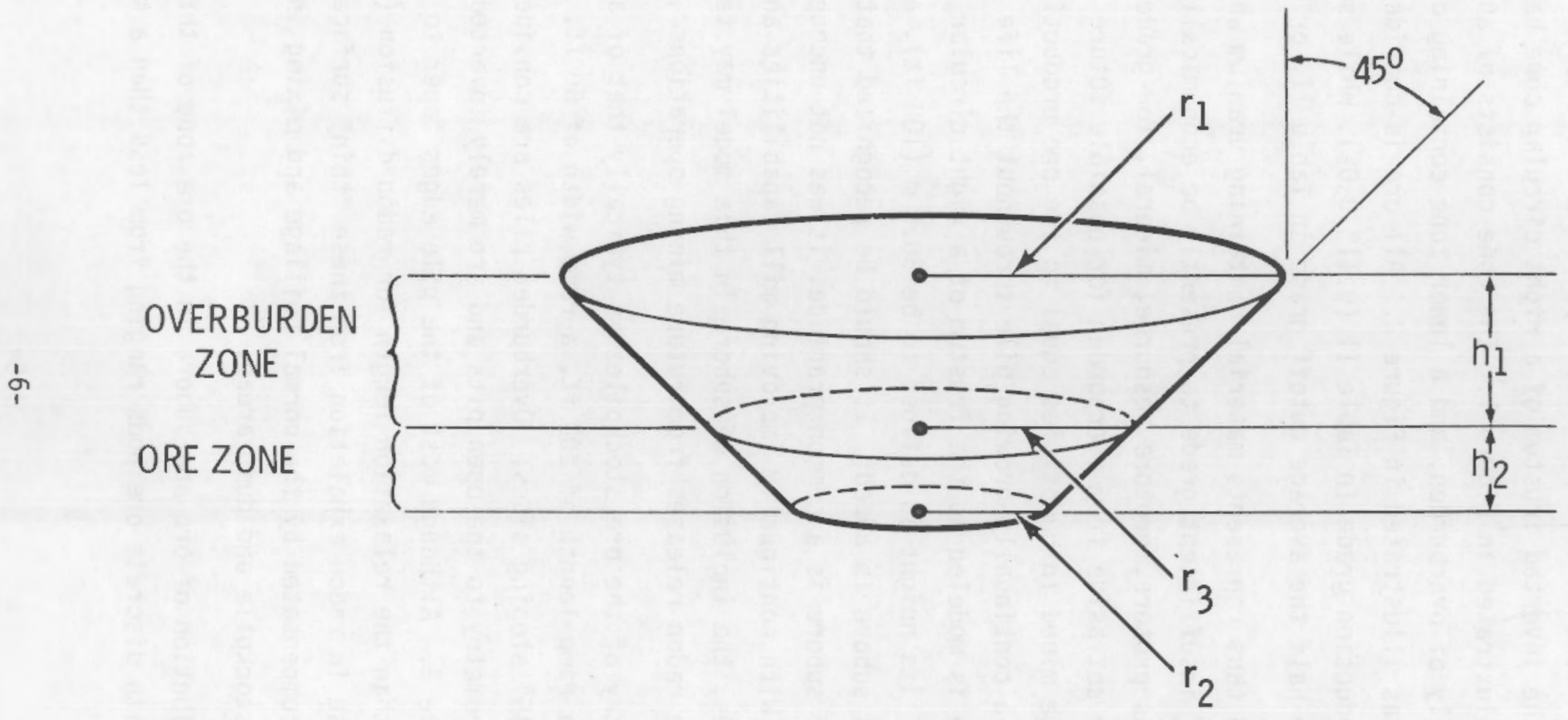

FIGURE 1. Schematic 0pen Pit 


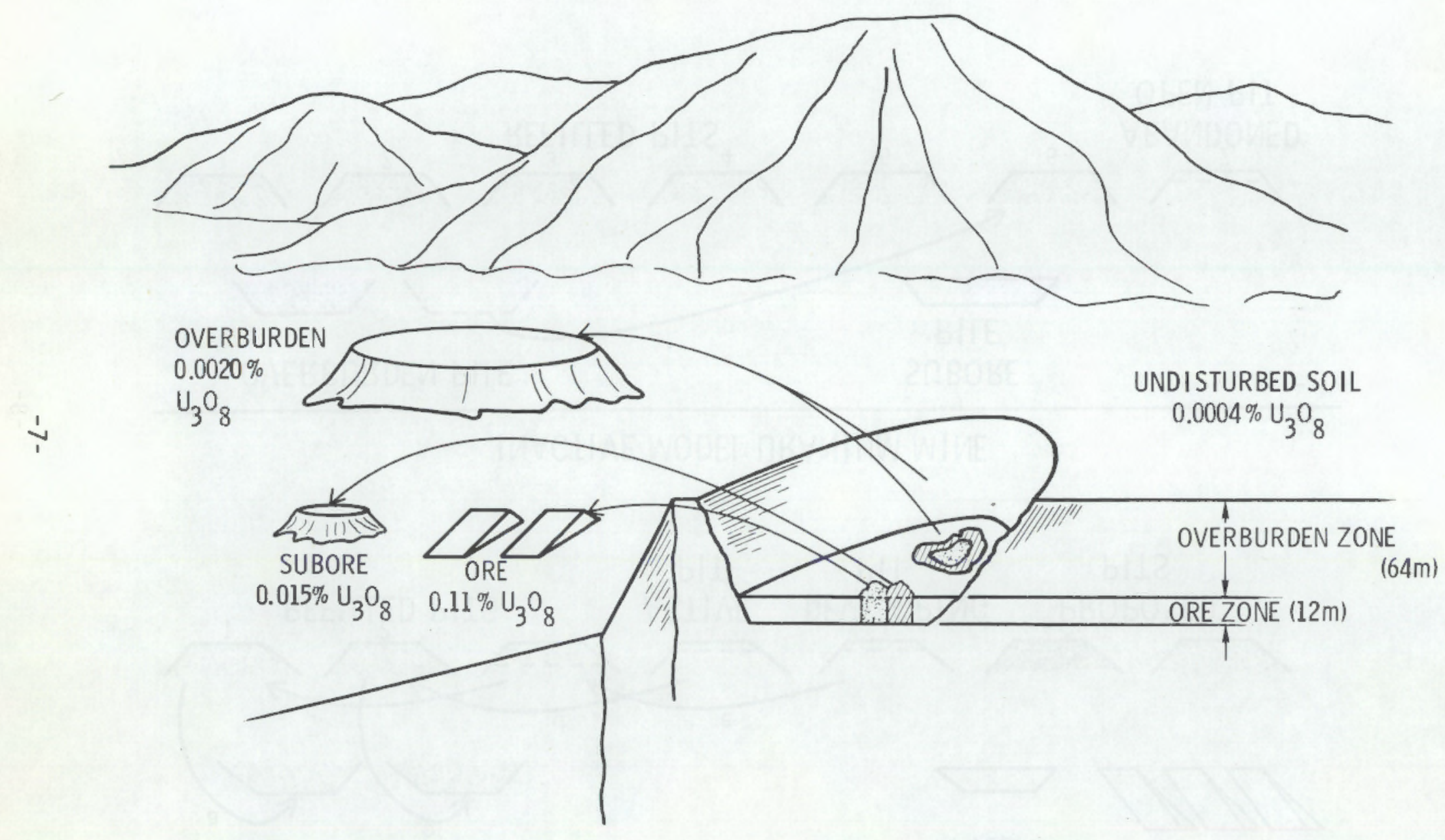

FIGURE 2. Model Open Pit Uranium Mining Operation 


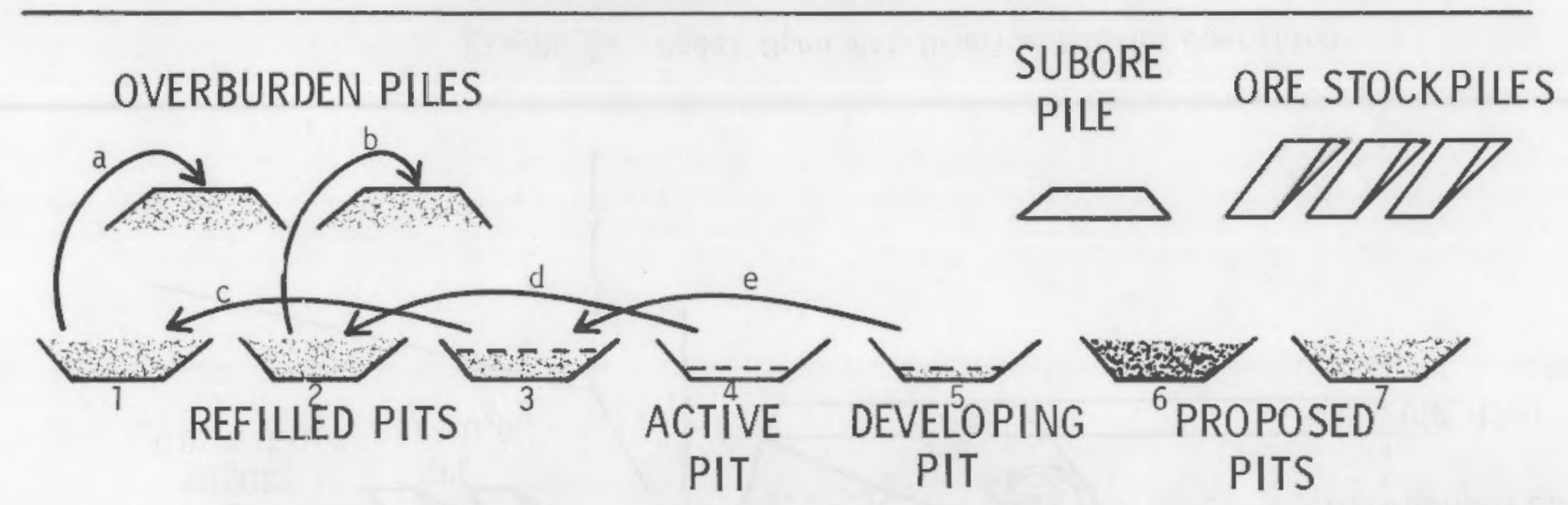

INACTIVE MODEL URANIUM MINE

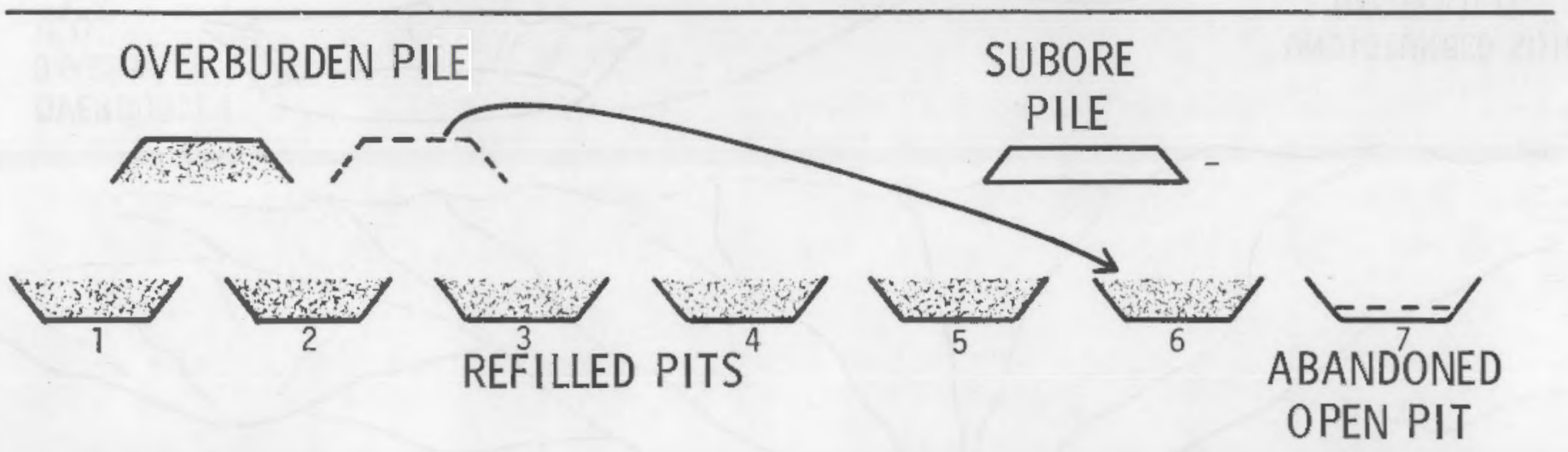

FIGURE 3. Schematic Illustration of the Model Mine Near the Middle of Its Active Lifetime, and in Its Inactive or Abandoned Status. 
than a hundred meters in extent. The subore usually occurs at the outer edges, or "shel]" of the ore pod, at the contact between the ore and the surrounding overburden material. Its proximity to the overburden results in frequent mixing of subore with the overburden extracted from the ore zone of the pit. To simplify the present calculations, ore and subore are assumed to have a constant latera? distribution with depth in the ore zone. This distribution is illustrated in Figure 2, where the ore and subore deposits are shown as vertical cylinders.

The model mining operation is viewed at two points in time in order to separately estimate the radon emissions during (a) active mining, and (b) the post-mining period. The first view of the mine, as illustrated in Figure 3, is near the middle of the mine's lifetime. The first two pits have been completely refilled. The third has been filled with the overburden from pit five except for that from the ore zone. The fourth pit is open and has been mined nearly to the bottom of the ore zone, and the fifth pit has just been developed or excavated to near the top of the ore zone, with no ore or subore yet exposed. The proposed sixth and seventh pits are not yet disturbed and therefore need not be considered. For simplicity of calculation, the exposed ore and subore surfaces in pit four are "thick" with respect to radon exhalation, despite their being at the bottom of the ore zone. Similarly, all surfaces in pit five are considered to consist of overburden with no radon release from the underlying ore or subore except through contamination of the overburden surfaces during excavation.

The view of the mine at its mid-life represents a status which actually exists over a large fraction of the mine's life. During the early development of pit one and pit two, surfaces yielding significant radon will be primarily the enlarging overburden piles, two pit surface areas exposed above the ore, and when the ore is reached, the ore surface. At this point no ore has been removed, but from this time on, the status of the multiple pit mine is quite well represented by that shown in Figure 3 , which is deemed "near the middle of its active lifetime." The status as far as surfaces for radon release is concerned will remain essentially the same from this point on until the mine is ready for abandonment just prior to returning the ore overburden pile to pit 6 . Thus the status of the mine depicted in Figure 3 
represents, for the purpose of radon release estimates, very nearly the status at any time in the active life of the mine, except during the excavation to reach ore in the first two pits.

The second view of the model mine, also shown in Figure 3 , is after the active mining period, and consists of six completely filled pits and a seventh one which is left open. Although two pits could conceivably remain open if the mine were abandoned, present reclamation regulations require a substantial final reclamation effort. The final mine status illustrated in Figure 3 is intended to be a compromise between the completely reciaimed mines anticipated for many future operations and the large abandoned open pits left by many past mining operations. The pile of subore, which was never used, is at its maximum size. The ore was completely milled and is no longer stockpiled. All ore was removed from the final pit, but the last of the subore was left in place. Again, radon exhalation estimates for overburden and subore assume the various deposits to be thick with respect to radon exhalation.

The ground swell which normally accompanies any excavation would preclude the overburden from actually fitting back into the conic pits as the model has described. The volume increase of 10-30\% has been neglected, however, in view of the wide variety of overburden handling methods in current use. The swell is partially offset by the removal of ore and subore and could be accomriodated with minimal impact in the model as a curved or domeshaped top surface for the refilled pits. In reality, the extent, shape, and depth of the pit is so variable that the potential increase in exposed overburden surface area due to ground swell is considered insignificant.

The uranium content of overburden is highly erratic, depending both on the natural uranium content of the constituent sand and on the decree of mixing with low grade ores during its removal. All overburden surfaces are assumed to contain $20 \mathrm{ppm} \mathrm{U}_{3} \mathrm{O}_{8}$, compared to surrounding undisturbed areas which are assumed to contain a background level of $4 \mathrm{ppm} \mathrm{U}_{3} \mathrm{O}_{8}$. $^{4}$ The nomina? 20 ppm value is based upon our observations up to the present time of radium in 22 overburden samples (average equivalent $U_{3} 0_{8}=19 \mathrm{ppm}$ ). It is 
a) consistent with the $24 \pm 8 \mathrm{ppm} \mathrm{U}_{3} \mathrm{O}_{3}$ concentration averaged from gammaray logging data from boreholes in overburden piles of six open pit mines by Kilborn/NUS, Inc., Denver, Colorado. (a) Radon exhalation fluxes measured at 31 points on an active overburden pile averaged $22 \mathrm{pCi} / \mathrm{m}^{2} \mathrm{sec}$. This compares with a radon exhalation rate of $5.8 \mathrm{pCi} / \mathrm{m}^{2} \mathrm{sec}$ based on accepted values for soil containing $20 \mathrm{ppm} \mathrm{U}_{3} \mathrm{O}_{8}$. The exhalation flux of $\mathrm{w}^{\mathrm{p}} \mathrm{pCi} / \mathrm{m}^{2} \mathrm{sec} \mathrm{sug}-$ gests either a lower uranium content or, more likely, a lower diffusion rate for radon in the overburden. The relatively high uranium content in overburden surfaces is probably a result of "inversion" of the overburden during stripping (i.e., deposition of uncontaminated material at the bottom of the pile followed by contaminated material from the ore zone at the top of the pile). Alternative mine planning or reclamation efforts could readily reduce this exhalation from overburden surfaces; however, data confirming radon fluxes from overburden surfaces to be significantly lower are presently inadequate.

The release of radon during truck loading and dumping is considered to be complete for the emanated fraction of radon. This fraction, assumed to be $20 \%$, is that part of the radon which has emanated from its parent sand grain into the interstitial soil gas. ${ }^{5}$ The release of radon from trucking occurs once for all subore and overburden and twice for the ore due to the two trips required from the pit to the stockpile and from the stockpile to the mi11 41 days later. All ore, subore, and overburden are considered to have a density of 1.78 tonnes $/ \mathrm{m}^{3}\left(1.50 \mathrm{ton} / \mathrm{yd}^{3}\right)^{(\mathrm{b})}$ and to be in equilibrium (radium to uranium). The availability of men and equipment is assumed to be 330 days/yr to allow for holidays, equipmert breakdowns, and other norma "outages."

An alternative mining procedure commonly called "continuous backfilling" was observed in some of the Wyoming mines. The method, which is ap-

(a) Data from a draft of a report by Donald W. Riedel and Norman F. Lewis, Estimates of Equivalent Uranium and Radon Flux for Uranium Mine Dumps Based on Natural Gamma Radioactivity.

(b) The density of ore, subore, and overburden can be quite variable depending upon moisture content, degree of aggregation, and compaction. Handbook values for dry sand range between about 1.2 and 1.5 tons $/ \mathrm{yd}^{3}$. We have chosen the nominal value of 1.50 tons $/ \mathrm{yd}^{3}$ which should be reasonably representative of loose sand with some moisture. 
plicable only to areas having contiguous or closely proximate ore bodies, involves excavation and mining from one side of the pit and backfilling the overburden on the other side. The resulting pit "moves" horizontally to follow the ore body as mining progresses. Surface areas of the pit may be comparable to those resulting from discrete pit mining, but the areas of exposed ore are potentially lower with the continuous backfill method. In this respect, the present model may slightly overestimate radon releases; however, the discrete pit method appears to be prevalent in both present and future mine plans.

\section{PRELIMINARY CALCULATIONS}

Effective Surface Area of Ore Stockpiles

The radon-exhaling surface area of stockpiled ore is calculated from the geometry of the ore stockpiles and the effective volume of stockpiled ore. Each load of ore is assumed to release all radon upon dumping, following which radon will build to full emanating rate in several days. A small correction in residence time on the ore pad should be made to account. for the time during which radon has not reached equilibrium; however, the correction is hardly justified when the rather wide variation in the stockpile size and shape from mine to mine and from time to time is taken into account. Furthermore, the ore most recently deposited may be the first to move to the mill. For these reasons, we assume that the volume on the stockpile is the product of days of backlog and daily mill capacity, or (41) $(1560)=63,960$ (rounded to 64,000 ) tonnes ore. The volume of the ore is thus $63,960 / 1.78$ tonnes $/ \mathrm{m}^{3}$, or 35,933 (rounded to 36,000 ) $\mathrm{m}^{3}$. Each stockpile is $8032 \mathrm{~m}^{3}$; thus there will be 4.5 stockpiles for the model mine, with a combined area of $10,800 \mathrm{~m}^{2}$.

Surface Area of the Subore Pi!e

The subore pile near the middle of the active mining period (after 8.5 yr a 330 days/yr) contains $2.46 \times 10^{6} \mathrm{~m}^{3}$ of subore. The frustum of a 100foot high $(30.5 \mathrm{~m})$ right circular cone with $45^{\circ}$ sloping sides having this volume has a base radjus of $174 \mathrm{~m}$ and a surface area of $1.09 \times 10^{5} \mathrm{~m}^{2}$. After the 17-yr active life of the Inine, the subore pile contains $4.92 \times 10^{6}$ $\mathrm{m}^{3}$ of subore. The corresponding pile has a base radius of $242 \mathrm{~m}$ and a surface area of $2.02 \times 10^{5} \mathrm{~m}^{2}$. 
Dimensions and Surface Areas of the Pits

An active open pit, illustrated as the fourth pit in Figure 3 , has been excavated through both the overburden and ore zones. Its volume is estimated from the ore production rate, the mine lifetime, the subore/ore ratio, the overburden/ore ratio, ore density, and number of pits as

$$
v_{p}=(1560)(330)(17)(2+77)\left(\frac{1}{1.78}\right)\left(\frac{1}{7}\right)=5.55 \times 10^{7} \mathrm{~m}^{3} \text {. }
$$

Modeling the pit as a conic section (Figure 1), the total pit volume may be defined as

$$
\text { where } \begin{aligned}
& v_{p}=\frac{\pi\left(h_{1}+h_{1}\right)}{3}\left(r_{1}^{2}+r_{1} r_{2}+r_{2}^{2}\right) \\
& r_{3}=r_{2}+\left(h_{1}+h_{2}\right) \text { and } \\
& r_{3}+h_{2}
\end{aligned}
$$

Solving for the various pit radii from the pit volume and the overburden and ore zone heights $\left(h_{1}=64 \mathrm{~m}, h_{2}=12 \mathrm{~m}\right)$, the radii illustrated in Figure 1 are $r_{1}=520 \mathrm{~m}, r_{2}=444 \mathrm{~m}$, and $r_{3}=456 \mathrm{~m}$. The surface area of the active pit is next caiculated as

$$
S_{\max }=\pi r_{2}^{2}+\pi \sqrt{2}\left(h_{1}+h_{2}\right)\left(r_{1}+r_{2}\right)=9.45 \times 10^{5} \mathrm{~m}^{2}
$$

This surface area also applies to each overburden pile and to the abandoned open pit. The surface area of the developing pit (pit 5 in Figure 3 ) is similarly estimated as

$$
S_{\text {dev }}=\pi r_{3}^{2}+\pi h_{1} \sqrt{2}\left(r_{1}+r_{3}\right)=9.31 \times 10^{5} \mathrm{~m}^{2}
$$

The top surface area of each refilled pit is simply $\pi r_{1}{ }^{2}=8.49 \times 10^{5} \mathrm{~m}^{2}$ each, with the exception of the third pit (Figure 3), which is lacking the overburden from the ore zone of pit 5 . The open volume for pit 3 equals the ore zone volume and is calculated from similar equations to those used above to give $7.63 \times 10^{6} \mathrm{~m}^{3}$. The resulting top surface area for pit 3 is similarly calculated to be $8.62 \times 10^{5} \mathrm{~m}^{2}$.

Surface Area of Ore and Subore in the Pits

The total volume of ore in a single pit is estimated from the ore production rate, the mine lifetime, number of pits and density as

$$
v_{\text {ore }}=(1560)(330)(17)\left(\frac{1}{7}\right)\left(\frac{1}{1.78}\right)=7.02 \times 10^{5} \mathrm{~m}^{3} \text {. }
$$


An equal volume in each pit is occupied by subore. Since the ore and subore are assumed to have a constant lateral distribution with depth in the 12-m ore zone, the surface area of exposed ore in the active open pit is estimated as

$$
\mathrm{S}_{\text {ore }}=\frac{7.02 \times 10^{5} \mathrm{~m}^{3}}{12 \mathrm{~m}}=5.85 \times 10^{4} \mathrm{~m}^{2}
$$

An equal area of subore is assumed to exist in the active open pit as we?l as in the abandoned open pit of the inactive mine.

Surface Area of Overburden in Active and Developing Pits, Refilled pits, Dump Piles, and the Abandoned Pit

The overburden surface area in the active open pit is estimated as the total pit area minus the areas occupied by ore and subore, and equals $8.28 \times 10^{5} \mathrm{~m}^{2}$. All other overburder surface areas equal their respective pit or pile surface areas except in the abandoned pit. Overburden in the abandoned pit covers the pit surface area minus the area of the subore left in the pit, or $8.86 \times 10^{5} \mathrm{~m}^{2}$.

The total overburden surface area for the active model uranium mine (Figure 3 ) is thus estimated as

- $2 \times 9.45 \times 10^{5} \mathrm{~m}^{2}$ for overburden piles,

- $2 \times 8.49 \times 10^{5} \mathrm{~m}^{2}$ for refilled pits,

- $8.62 \times 10^{5} \mathrm{~m}^{2}$ for partially refilled pit,

- $8.28 \times 10^{4} \mathrm{~m}^{2}$ for active pit,

- $9.31 \times 10^{5} \mathrm{~m}^{2}$ for deveioping pit,

giving a total of $6.21 \times 10^{6} \mathrm{~m}^{2}$. The inactive mine (Figure 3 ) similarly involves a total overburden surface of

- $9.45 \times 10^{5} \mathrm{~m}^{2}$ for overburden pile,

- $6 \times 8.49 \times 10^{5} \mathrm{~m}^{2}$ for refilled pits,

- $8.86 \times 10^{5} \mathrm{~m}^{2}$ for abandoned pit,

for a total of $6.93 \times 10^{6} \mathrm{~m}^{2}$.

Area of Original Land Surface Affected by the Mine

The active model mine entails disturbance of original land areas equal to the top planar surface at all pit locations, plus the areas covered by 
the bottom of all ore, subore, and overburden piles. The subore pile covers an area of $\pi(175 \mathrm{~m})^{2}=9.6 \times 10^{4}$, and the ore stockpiles cover an area of $2400 \mathrm{~m}^{2}$ each. The disturbed land surface area for the active mine is thus

- $2 \times 8.49 \times 10^{5} \mathrm{~m}^{2}$ for overburden piles,

- $5 \times 8.49 \times 10^{5} \mathrm{~m}^{2}$ for pits.

- $9.6 \times 10^{4} \mathrm{~m}^{2}$ for subore piles.

- $4.5 \times 2000 \mathrm{~m}^{2}$ for ore piles.

or a total of $6.05 \times 10^{6} \mathrm{~m}^{2}$.

The inactive model mine (Figure 3 ) is similarly estimated to disturb the following original land surfaces:

- $8.49 \times 10^{5} \mathrm{~m}^{2}$ for overburden piles,

- $7 \times 8.49 \times 10^{5} \mathrm{~m}^{2}$ for pits,

- $1.84 \times 10^{5} \mathrm{~m}^{2}$ for subore pile,

or a total of $6.98 \times 10^{6} \mathrm{~m}^{2}$. The area covered by the second overburden pile is considered to have been sufficiently reclaimed to not leave persisting mine-related radon sources.

\section{Radon Exhalation Rate}

Various estimates of radon exhalation are reported for ore and soil surfaces, some of which are listed in Table III. As indicated, the rates we have measured from various surfaces of ore at one of the Wyoming open pit uranium mines are of comparable magnitude to the other estimates. They include 22 measurements in the pit and on ore and subore piles, and were taken over a variety of seasonal, moisture, and temperature conditions. The one-sigma confidence interval for our mean unit radon flux is 0.19 $0.46 \mathrm{pCi} / \mathrm{cm}^{2} \mathrm{sec} \% \mathrm{U}_{3} \mathrm{O}_{9}$. Thirty-two additional measurements of the unit radon flux from overburden and undisturbed soil surfaces gave a somewhat lower mean, but are not used here due to the great inhomogeneities in these materials and the resulting variance in results. Our average measured exhalation rate of $0.29 \mathrm{pCi} / \mathrm{cm}^{2} / \mathrm{sec} \% \mathrm{U}_{3} \mathrm{O}_{8}$ is used in the present caiculatiuns as $0.092 \mathrm{Ci} / \mathrm{m}^{2} / \mathrm{yr} \% \mathrm{U}_{3} \mathrm{O}_{8}$ after converting from the units in Table III. 


\section{TABLE III}

\section{Estimates of the Radon Flux Exhaled from the Ground Surface}

\begin{tabular}{|c|c|c|}
\hline$\left(\mathrm{pCi} / \mathrm{cm}^{2} \sec \% \mathrm{U}_{3} \mathrm{O}_{8}\right)$ & Surface & Reference \\
\hline 0.29 & Ore in open pit mine & This work \\
\hline 0.33 & Tailings & Silker, et al ${ }^{\epsilon}$ \\
\hline 0.24 & Soi1 & Junge $^{7}$ \\
\hline $0.25^{(\mathrm{a})}$ & Soil & Wilkening and Hand ${ }^{8}$ \\
\hline 0.062 & Soil & Clements and Wilkening 9 \\
\hline
\end{tabular}

(a)

$\left(0.25 \mathrm{pCi} / \mathrm{cm}^{2} \sec \%\right) \times\left(0.0004 \% \mathrm{U}_{3} \mathrm{O}_{8}\right)$ qives $1 \mathrm{pCi} / \mathrm{m}^{2}$ sec, the background exhalation rate used in the generic environmental impact statement on uranium milling. ${ }^{10}$

\section{RADON EMISSION FROM THE ACTIVE MODEL MINE}

Radon emissions are calculated as the product of surface area, ore grade, and the unit radon flux for all exhaling surfaces in the mine. Radon releases due to truck loading and dumping are estimated as the product of the uranium concentration, the production or haulage rate, the number of trips made, the emanation fraction (0.2), and the unit radon activity $\left(0.0050 \mathrm{Ci} / \mathrm{m}^{3} \% U_{3} O_{8}\right)$. The production rates for ore and subore are both $2.89 \times 10^{5} \mathrm{~m}^{3} / \mathrm{yr}$, and that for overburden is 77 times greater, or $2.23 \times$ $10^{7} \mathrm{~m}^{3} / \mathrm{yr}$. The net radon release caused by mining is estimated by subtracting from the total emissions the natural background radon flux of $3.68 \times 10^{-5} \mathrm{Ci} / \mathrm{m}^{2}$ yr times the area of $6.05 \times 10^{6} \mathrm{~m}^{2}$ disturbed by mining. The total and net radon emissions from the active model mine are summarized in Table IV. 
TABLE IV

Net Radon Emissions from the Active Model Mine

Source

Active pit (No. 4)

Ore

Subore

Overburden

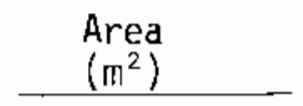

Partially filled pit (No. 3)

overburden

Dump piles

Subore

Overburden

Stockpiles

Ore

Truck dumping

Ore

Subore

overburden

TOTAL RADON EMISSION/YR

Natural background

emissions from surfaces

affected by mining

$6.05 \times 10^{6}$

NET INCREASE IN RAOON EMISSIONS DUE TO MINING
$5.85 \times 10^{4}$

$5.85 \times 10^{4}$

$8.28 \times 10^{5}$

$9.31 \times 10^{5}$

$2 \times 8.49 \times 10^{5}$

20

312

$8.62 \times 10^{5}$

20

159

Grade Emission Rate ( $\mathrm{Ci} / \mathrm{yr})$

592

81

152

177

$1.09 \times 10^{5} \quad 150$

150

$2 \times 9.45 \times 10^{5} \quad 20 \quad 348$

$1.08 \times 10^{4}$

1100

109

1100

64

150

$20 \quad 45$

2187

4

$-223$ 
Since the active model mine produces 1560 tonnes/day of $0.11 \% \quad \mathrm{U}_{3} \mathrm{O}_{3}$ ore during 330 days/yr, its equivalent $\mathrm{U}_{3} \mathrm{O}_{8}$ output is 566 tonnes/yr. The fuel requirement for an operating 1000 megawatt electric power plant using a light water reactor has been estimated at 182 tonnes $U_{3} 0_{8}$ annually. ${ }^{11} \mathrm{~A}$ "Reference Reactor Year" (RRY) is thus defined as 182 tonnes $\mathrm{U}_{3} \mathrm{O}_{8}$, and the active model mine's production can be expressed as $3.11 \mathrm{RRY} / \mathrm{yr}$. The 1964 $\mathrm{C} j / \mathrm{yr}$ of radon released by the active model mine (Table IV) is thus equivalent to $630 \mathrm{Ci} / \mathrm{RRY}$. An alternative definition of the RRY has been suggested due to the omission of the uranium mill efficiency in the original definition. ${ }^{10}$ If a $90.5 \%$ recovery of uranium from uranium ore is obtained by the mill, a definition of 201 tonnes $U_{3} 0_{8} / R R Y$ results. ${ }^{12}$ The active model mine produces $2.82 \mathrm{RRY} / \mathrm{yr}$ and emits $u 700 \mathrm{Ci} / \mathrm{RRY}$ using this definition. Radon emissions from the entire U. S. open pit uranium mining industry can be estimated from the $23.5 \mathrm{Ci}$ /tonne $\mathrm{U}_{3} \mathrm{O}_{3}$ figure developed here, or can be more accurately estimated by compiling data such as in Table II on all U.S. open pits and related surface areas and applying the appropriate exhalation fluxes.

RADON EMISSION FROM THE INACTIVE OR ABANDONED MINE

Radon emissions are calculated in a similar fashion for the inactive. or abandoned mine as it is illustrated in figure 3 . These radon releases are sumarized in Table $V$. Since the model mine will produce 9620 tonnes $\mathrm{U}_{3} \mathrm{O}_{8}$ during its $77-y \mathrm{r} 1 \mathrm{ifetine}$, the emission of $1380 \mathrm{Ci} / \mathrm{yr}$ from Table $\mathrm{V}$ should be viewed as $26 \mathrm{Ci} / \mathrm{yr} / \mathrm{RRY}$ using the 182 tonnes $\mathrm{U}_{3} \mathrm{O}_{3} / \mathrm{RRY}$ definition, or $29 \mathrm{Ci} / \mathrm{yr} / \mathrm{RRY}$ using 201 tonnes $\mathrm{U}_{3} \mathrm{O}_{8} / \mathrm{RRY}$.

Radon emissions from the abandoned open pit would probably decrease with time due to several natural reclamation effects which would occur. Since the pits are generally below the water table, the abandoned pit would soon become covered with water, greatly reducing radon exhalation. The steep pit walls would also slough, depositing relatively uncontaminated surface rock on the ore-zone rock in the pit bottom. Possible wind dispersion of the subore pile would offset these decreases, however, making long-range projections impossible without further definition of the reclamation efforts. Covering of old pits and pile surfaces with topsoil or other clean material could greatly reduce the lingering radon emissions and is likely to be a standard practice at many of the mines comprising this model. 
TABLE $V$

\section{Radon Emissions from the Inactive or Abandoned Model Mine}

Source

Abandoned pit

Subore

Overburden

Refilled pits

overburden

Dump piles

Subore

0verburden

TOTAL RADON EMISSIONS

Natural background emissions from surfaces

affected by mining

NET INCREASE IN RADON EMISSIONS DUE TO MINING

$6 \times 8.49 \times 10^{5}$

$2.02 \times 10^{5}$

$9.45 \times 10^{5}$

$6.98 \times 10^{6}$
Net Grade

(ppm $\mathrm{U}_{3} \mathrm{O}_{8}$ )

Emission Rate ( $\mathrm{C} / \mathrm{yr}$ )

81

163

150

20

20

937

150

279

20

174

1634

4

$-257$

1377

\section{COMPARISON OF RADON EMISSION WITH BACKGROUND LEVELS}

The previous calculations of the net radon emission of the model open pit uranium mine may be put in perspective with the normal or background radon emission rate of the affected land areas by the following estimates. For the active mining period, the $6.05 \mathrm{~km}^{2}$ of originally undisturbed land would have emitted radon at the rate of $223 \mathrm{ci} / \mathrm{yr}$. The model mine has thus increased the background radon emission rate of the affected area by a factor of

$$
\frac{2187 \mathrm{Ci} / \mathrm{yr} \text { (active mine) }}{223 \mathrm{Ci} / \mathrm{yr}(\text { no mine })}=9.8
$$

during the active mining period.

Similarly, for the abandoned or inactive mine, the $7.0 \mathrm{~km}^{2}$ of land affected by the mining operation would have emitted radon at the rate of 
$257 \mathrm{Ci} / \mathrm{yr}$. The entire operation thus raised the radon emission rate of the affected area by a factor of

$$
\frac{1634 \mathrm{Ci} / \mathrm{yr} \text { (abandoned mine) }}{257 \mathrm{Ci} / \mathrm{yr} \text { (no mining) }}=6.3 \text { for the post-mining period. }
$$

Since ald eight of the open pit uranium mines comprising the model mine lie within an 80-mile $(129 \mathrm{~km})$ radius of Casper, Wyoming, the impact of the model mine on an area of this size $\left(52,000 \mathrm{~km}^{2}\right.$ or 20,000 square miles) may be of interest. Assuming the area to have a background radon emission rate equivalent to the $4 \mathrm{ppm} \mathrm{U}_{3} \mathrm{O}_{8}$ level, the model mine would increase the radon emission of the Casper vicinity by a factor of

$$
1+\frac{\left(6.05 \mathrm{~km}^{2}\right)(9.8)}{\pi(129 \mathrm{~km})^{2}}=1.001 \text {, or } 0.1 \% \text { increase }
$$

during active mining, and

$$
1+\frac{\left(7.0 \mathrm{~km}^{2}\right)(6.3)}{\pi\left(129 \mathrm{~km}^{2}\right.}=1.0008 \text {, or } 0.08 \% \text { increase }
$$

after cessation of mine activities.

\section{SUMMARY}

Active mining in the model open pit uranium mine causes net radon reTeases of $22000 \mathrm{Ci} / \mathrm{yr}$, compared to $220 \mathrm{Ci} / \mathrm{yr}$ naturally exhaled radon from the $6 \mathrm{~km}^{2}$ mine area. In terms of annual reactor fuel requirements, this is equivalent to $630 \mathrm{Ci} / \mathrm{RRY}$ (182 tonnes $\mathrm{U}_{3} \mathrm{O}_{8} / \mathrm{RRY}$ ). Radon releases would continue at the reduced rate of $01400 \mathrm{Ci} / \mathrm{yr}$ after the $17-\mathrm{yr}$ lifetime of the mine, assuming no changes in the physical environment with time. This may be compared with $2260 \mathrm{Ci} / \mathrm{yr}$ naturally exhaled radon from an equivalent undisturbed $7 \mathrm{~km}^{2}$ area. The continuing radon releases due to the model mine are equivalent to $26 \mathrm{Ci} / \mathrm{yr}$ per RRY produced by the mine (182 tonnes $\mathrm{U}_{3} \mathrm{O}_{8} / \mathrm{RRY}$ ). 


\section{REFERENCES}

3. U. S. Department of Energy, Statistical Data of the Uranium Industry, G30-100(78), Grand Junction Office, Grand Junction, $\mathrm{CO}, \mathrm{p} .15$, January 1978.

2. S. Dayton, "Uranium." Engineering and Mining Journa?, Vol. 179, No. 11, p. 87, November 1978 .

3. B. Perkins, An Overview of the New Mexico Uranium Industry. New Mexico Energy and Minerals Department, Santa Fe, NM, p. 101 , January 1979.

4. Ford, Bacon, and Davis, Utah, Inc., Phase II, Title I, Engineering Assessment of Inactive Uranium Mill Tailings. The reference of $4 \mathrm{ppm}$ is derived from averaging site specific data presented in GJT-3, -5 , $-8,-10,-13,-14,-15,-17,-19,-20$. Each report bears the same title, but each is for a different mill site. Reports were prepared for the Grand Junction Office of the Department of Energy, Grand Junction, CO, 1977.

5. P. J. MacBeth, C. M. Jensen, V. C. Rogers, R. F. Overmyer, Laboratory Research on Tailings Stabilization Methods and Their Effectiveness in Radiation Containment. GJT-2i, Ford, Bacon, and Davis, Utah, Inc., Apri1 1978.

6. W. B. Silker, N. A. Wogman, C. W. Thomas, D. B. Carr, and P. C. Heasler, "Measurement of Radon Diffusion and Exhalation from Uranium Mill Tailings Piles." Environmental Science and Technology, Volume 13, No. 8, pp. 962-4, August 1979.

7. C. E. Junge, Air Chemistry and Radioactivity. Academic Press, New York, NY, PP 209-285, 1963 .

8. M. H. Wilkening and J. E. Hand, "Radon Flux at the Earth-Air Interface." J.Geophys. Res. 65:3367-3370, 1960 .

9. W. E. Clements and M. H. Wilkening, "Atmospheric Pressure Effects on $222 \mathrm{Rn}$ Transport Across the Earth-Air Interface." J. Geophys. Res. 79: 5025-5029, 1974.

10. U. S. Nuclear Regulatory Commission, Draft Generic Environmental Impact Statement on Uranium Milling. NUREG-0511, Vols. I and II, U. S. Nuclear Regulatory Commission, Washington, D. C., Apri1 1979.

11. U. S. Atomic Energy Commission, Environmental Survey of the Uranium Fuel Cycle, WASH-1248. U. S. Atomic Energy Commission, Fuels and Materials, Directorate of Licensing, Washington, D. C., p. A-8, Table A-2, Apri1 7974.

12. U. S. Nuclear Regulatory Commission, Final Generic Environmental Statement on the Use of Recycle Plutonium in Mixed Oxide Fuel in Light Water Cooled Reactors. NUREG-0002. U. S. Nuclear Regulatory Comisision. Office of Nuclear Material, Washington, D. C., August 1976. 
, 
NUREG-CR-0628

PNL-2889, REV. $\mathrm{RE}$

\section{DISTRIBUTION}

No. of

Copies

OFFSITE

A. A. Churm

DOE Patent Division

9800 S. Cass Avenue

Argonile, IL 60439

345 U.S. Ruclear Regulatory Commission

Djvision of Tecrnicui Information and Document Control

7920 Norfolk Avenue

Bethesda, MD $200 j 4$

2 DOE Technical Inforration Center

Washington, D. C. 20545

250 William E. Thompson

Technology Assessment Branch

Division of Fuel Cycle and Material Safety

U. S. Nuclear Regulatory Comission

Washington, D. C. 20555

William E. Gray, Manager

Environmental Engineering

Anaconda Company

660 Bannock Street

Denver, C0 80204

Edward E. Kennedy, Manager

Environmental Engineering

United Nuclear-Homestake

Partners Corporation

P.0. Box 98

Grants, NM 87020

H. J. Abbiss, Vice President

Environmental \& Safety

Services

United Nuclear Corporation

Mining and Milling Division

P. 0. Box 3951

Albuquerque, NM 87110
No. of

Copies

OFFSITE (continued)

James E. Cleveland

Environmental Engineer

Kerr-McGee Nuclear Corporation

P.0. Box 218

Grants, NM 87020

Tom Buht

Regiona1 Ore office

State of New Mexico

Health and Social Services

Department

Environmental Improvement Agency

P.0. Box 968

Santa Fe, NM 87503

Arthur Miller, Vice President

Reserve $0 i 1$ and Minerals Corp.

Suite 308

20 First Plaza

A1buquerque, NM 87102

Jim Roselle

Ranchers Exploration and Development Corporation

P.0. Box 6217

Albuquerque, NM 87107

Jack Rothflejsch

U. S. Nuclear Regulatory Commission

Nuclear Materials, Safety, and Safeguards

Washington, D. C. 20555

William 3. Shelley, Director

Regulation and Control

Kerr-McGee Nuciear Corporation

123 Robert S. Kerr Avenue

2205 McGee Tower

Oklahoma City, OK 73125

Laura Santos

Office of Nuclear Regulatory Research

Division of Safeguards, Fuel Cycle and Environmenta] Research

Mail Stop 1130 SS

Washington, D.C. 20555 
NUREG/CR-0628

PNL-2889, REV.

RE

No. of Copies

ONSITE

50 Pacific Northwest Laboratory

W. I. Enderlin

W. D. Felix

J. A. Glissmeyer

K. K. Nielson (30)

R. W. Perkins (6)

L. C. Schwendiman

$V$. W. Thomas

W. R. Wiley

N. A. Wogman

Technical Information (5)

Publishing Coordination (2) 